\title{
CAPZA2 wt Allele
}

National Cancer Institute

\section{Source}

National Cancer Institute. CAPZA2 wt Allele. NCI Thesaurus. Code C132073.

Human CAPZA2 wild-type allele is located in the vicinity of 7q31.2 and is approximately $111 \mathrm{~kb}$ in length. This allele, which encodes F-actin-capping protein subunit alpha-2 protein, plays a role in the modulation of actin polymerization. 